\title{
ESTIMATE OF REFERENCE EVAPOTRANSPIRATION THROUGH CONTINUOUS
} PROBABILITY MODELLING

Doi:http://dx.doi.org/10.1590/1809-4430-Eng.Agric.v37n2p257-267/2017

\section{EDUARDO M. ULIANA ${ }^{1 *}$, DEMETRIUS D. DA SILVA², JOSÉ G. F. DA SILVA ${ }^{3}$, MICAEL DE S. FRAGA ${ }^{2}$, LUANA LISBOA ${ }^{4}$}

${ }^{1 *}$ Corresponding author. Universidade Federal de Mato Grosso/ Sinop - MT, Brasil. E-mail:morganuliana@ufmt.br

\begin{abstract}
This study aimed at testing the fit of continuous probability distributions to a daily reference evapotranspiration dataset $\left(\mathrm{ET}_{0}\right)$ at a $75 \%$ probability level for designing of irrigation systems. Reference evapotranspiration was estimated by the Penman-Monteith method (FAO-56PM) for eight locations, within the state of Espírito Santo (Brazil), where there are automatic gauge stations. The assessed probability distributions were beta, gamma, generalized extreme value (GEV), generalized logistic (GLO), generalized normal (GN), Gumbel (G), normal (N), Pearson type 3 (P3), Weibull (W), two- and three-parameter lognormal (LN2 and LN3). The fitting of the probability distributions to the $\mathrm{ET}_{0}$ daily dataset was checked by the Kolmogorov-Smirnov's test. Among the studied distributions, GN was the only one to fit the $\mathrm{ET}_{0}$ data for all studied months and locations. We should also infer that continuous probability models have a good fit to the studied $\mathrm{ET}_{0}$ dataset, enabling its estimation at $75 \%$ probability through a Generalized Normal distribution (GN). Therefore, it can be used for the sizing of irrigation systems according to a given degree of risk.
\end{abstract}

KEYWORDS: evapotranspiration, probability, irrigation.

\section{INTRODUCTION}

ALLEN et al. (1998) defined reference evapotranspiration $\left(\mathrm{ET}_{0}\right)$ as being the evapotranspiration of a hypothetical crop with a height of $12 \mathrm{~cm}$, albedo of 0.23 , and surface aerodynamics resistance of $70 \mathrm{~s} \mathrm{~m}^{-1}$. According to SAAD et al. (2002), $\mathrm{ET}_{0}$ is a fundamental variable for estimation of crop water demand, which will influence on the designing of an irrigation system. However, there have still challenges to set insightfully evapotranspiration role on the designing of irrigation systems. The above-mentioned authors concluded that using solely $\mathrm{ET}_{0}$ monthly averages for irrigation scaling might lead to an underestimation thereof while adopting ET $_{0}$ maximum daily values can over-estimate them.

$\mathrm{The} \mathrm{ET}_{0}$ can be determined by direct and indirect methods. Direct methods include lysimeters, field experimental plots, and soil moisture control. Among the indirect ones are those based on evaporimeters (US Weather Bureau and class A pan), equations (Penman-Monteith, BlaneyCriddle, Hargreaves-Samani, etc) among others.

Among the proposals to determine $\mathrm{ET}_{0}$, we may highlight the one suggested by SILVA et al. (1998) and SAAD et al. (2002). This directive considers the probability of evapotranspiration to occur, providing an adequate design of an irrigation system. In addition, this method allows the user to choose the degree of risk (non-meeting of crop water requirements) for a given system. In Brazil, a probability of $75 \%$ has been taken as acceptable for irrigation projects (ASSIS et al., 2014; BERNARDO et al., 2006). At this level, it is expected that the amount of evaporated will be greater than the depth designed for the project only once every 4 years.

Given the above, our study aimed to verify the fit of continuous probability distributions to a dataset of daily reference evapotranspiration, at $75 \%$ probability, for eight locations within the state of Espírito Santo, for its further use in irrigation system designing.

\footnotetext{
${ }^{2}$ Universidade Federal de Viçosa/ Viçosa - MG, Brasil.

${ }^{3}$ Instituto Capixaba de Pesquisa, Assistência Técnica e Extensão Rural/ Vitória - ES, Brasil.

${ }^{4}$ Companhia de Pesquisa de Recursos Minerais/ Manaus - AM, Brasil. 


\section{MATERIAL AND METHODS}

Reference evapotranspiration was estimated for eight locations in the state of Espírito Santo. Each site has an automatic gauge station from where data were gathered. The geographical location of these stations and respective cities to which they belong can be seen on the map in Figure 1. Table 1 contains information regarding the used automatic gauge stations that belong to the Brazilian Meteorological Institute (INMET).

The meteorological data used were respective to the period between 2007 and 2011. We used a data series relatively small for the stations being in operation only since 2006.

TABLE 1. Information regarding the weather stations used in the study.

\begin{tabular}{ccccc}
\hline INMET Code & Location city & Latitude & Longitude & Altitude (meters) \\
\hline A617 & Alegre & $-20^{\circ} 45^{\prime} 2.1^{\prime \prime}$ & $-41^{\circ} 29^{\prime} 20^{\prime \prime}$ & 138 \\
A615 & Alfredo Chaves & $-20^{\circ} 38^{\prime} 11^{\prime \prime}$ & $-40^{\circ} 44^{\prime} 29^{\prime \prime}$ & 35 \\
A614 & Linhares & $-19^{\circ} 21^{\prime} 24^{\prime \prime}$ & $-40^{\circ} 04^{\prime} 07^{\prime \prime}$ & 40 \\
A623 & Nova Venécia & $-18^{\circ} 41^{\prime} 43^{\prime \prime}$ & $-40^{\circ} 23^{\prime} 26.8^{\prime \prime}$ & 154 \\
A622 & Presidente Kennedy & $-21^{\circ} 06^{\prime} 4.3^{\prime \prime}$ & $-41^{\circ} 02^{\prime} 20^{\prime \prime}$ & 80 \\
A616 & São Mateus & $-18^{\circ} 42^{\prime} 50^{\prime \prime}$ & $-39^{\circ} 50^{\prime} 53.8^{\prime \prime}$ & 39 \\
A613 & Santa Teresa & $-19^{\circ} 59^{\prime} 19^{\prime \prime}$ & $-40^{\circ} 34^{\prime} 45.8^{\prime \prime}$ & 998 \\
A612 & Vitória & $-20^{\circ} 18^{\prime} 56.1^{\prime \prime}$ & $-40^{\circ} 19^{\prime} 02^{\prime \prime}$ & 9 \\
\hline
\end{tabular}

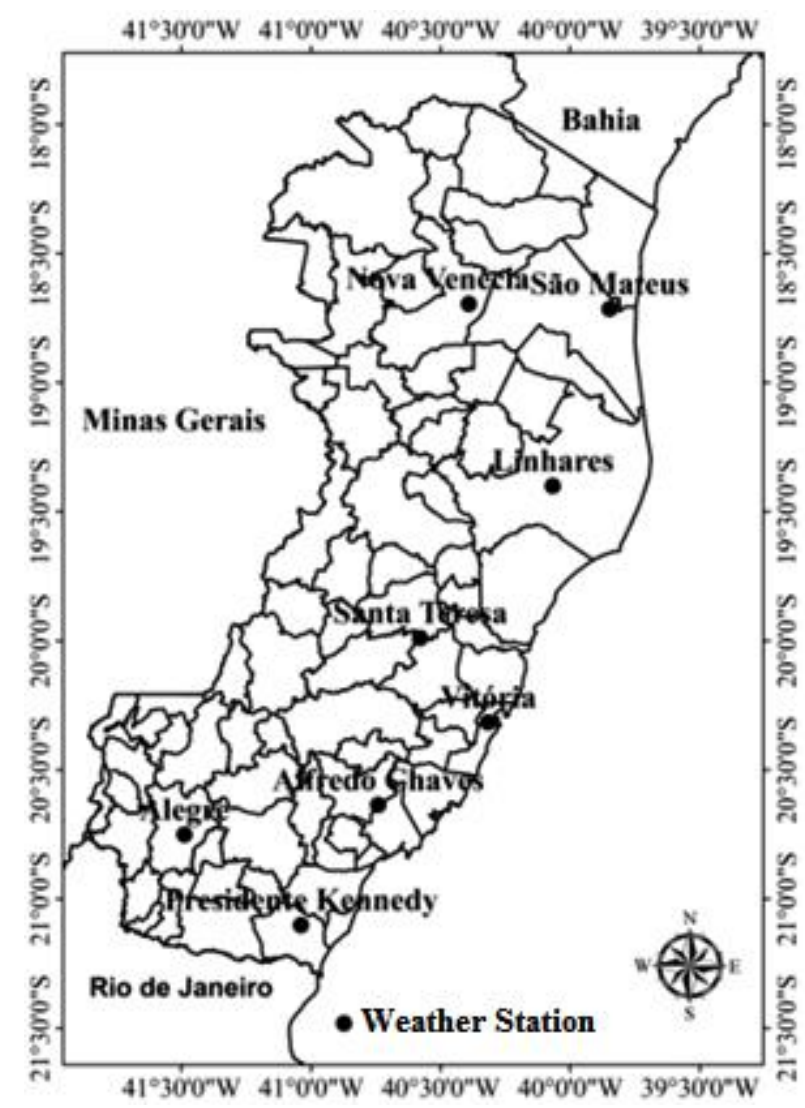

FIGURE 1. Location of the automatic weather stations used in the study.

The reference evapotranspiration was estimated by the Penman-Monteith method - FAO-56, as stated by ALLEN et al. (1998), by means of the following equation:

$$
\mathrm{ET}_{0}=\frac{0,408 \Delta(\mathrm{Rn}-\mathrm{G})+\gamma \frac{900}{\mathrm{~T}+273} \mathrm{U}_{2}\left(\mathrm{e}_{\mathrm{s}}-\mathrm{e}_{\mathrm{a}}\right)}{\Delta+\gamma\left(1+0,34 \mathrm{U}_{2}\right)}
$$


in which,

$\mathrm{ET}_{0}$ is the reference evapotranspiration $\left(\mathrm{mm} \mathrm{d}^{-1}\right)$;

$\mathrm{Rn}$ is the radiation balance $\left(\mathrm{MJ} \mathrm{m}^{-2}\right)$;

G is the density of heat flow from the soil $\left(\mathrm{MJ} \mathrm{m}^{-2}\right)$;

$\mathbf{T}$ is the mean air temperature $\left({ }^{\circ} \mathrm{C}\right)$;

$\mathrm{U}_{2}$ is the wind speed at 2 meters above the soil $\left(\mathrm{m} \mathrm{s}^{-1}\right)$;

$\mathbf{e}_{\mathbf{s}}$ is the saturation vapor pressure $(\mathrm{kPa})$;

$\mathbf{e}_{\mathrm{a}}$ is the partial vapor pressure $(\mathrm{kPa})$;

$\Delta$ is the slope of the saturation vapor pressure curve at a T temperature $\left(\mathrm{kPa}^{\circ} \mathrm{C}^{-1}\right)$,

$\mathrm{Y}$ is the psychrometric coefficient $\left(\mathrm{kPa}^{\circ} \mathrm{C}^{-1}\right)$.

Even though this method requires a great number of climatic elements, it has been widely used as scientific studies have proved its satisfactory performance when compared to lysimetric measurements (OLIVEIRA et al., 2008; BARROS et al., 2009; CAVALCANTE JUNIOR et al., 2011).

We assessed the following distributions: beta, gamma, generalized extreme value (GEV), generalized logistic (GLO), generalized normal (GN), Gumbel (G), normal (N), Pearson type 3 (P3), Weibull (W), two- and three-parameter lognormal (LN2 and LN3). These distributions are described by NAGHETTINI \& PINTO (2007) and HOSKING (2013).

The probability density function of the gamma distribution is given by:

$$
f(x)=\frac{x^{\alpha-1} e^{\left(-\frac{x}{\beta}\right)}}{\beta^{\alpha} \Gamma(\alpha)}
$$

in which,

$a$ is the form parameter,

$\boldsymbol{\beta}$ is the scale parameter, and

$\Gamma$ is the gamma function.

GEV distribution, with a location parameter $\xi$, scale $\mathbf{a}$ and form $\mathbf{K}$, has the following probability density function:

$$
f(x)=e^{[-(-x)]}
$$

in which,

$$
\mathrm{y}=\mathrm{K}^{-1} \log \{1-\mathrm{K}(\mathrm{x}-\xi) / \alpha\}
$$

GLO probability density function with a location parameter $\xi$, scale ${ }^{a}$, form $\mathrm{k}$, is given by:

$$
f(x)=\frac{1}{1+e^{-y}}
$$

in which,

$$
\mathrm{y}=\mathrm{k}^{-1} \log \left[\frac{1-\mathrm{k}\left(\mathrm{x}-\xi^{2}\right)}{\alpha}\right]
$$


GN distribution, with a location parameter $\xi$, scale $a$, form $\mathrm{k}$, has the following probability density function:

$$
\mathrm{f}(\mathrm{x})=\Phi(\mathrm{y})
$$

in which,

$$
\mathrm{y}=-\mathrm{K}^{-1} \log \left\{1-\mathrm{k}\left(\mathrm{x}-\xi^{-}\right) / \alpha\right\}
$$

and

$\Phi(\mathrm{y})$ is the distribution function of the standard normal distribution. by:

Gumbel probability density function with a location parameter $\xi$, scale $\mathbf{a}$, form $\mathrm{k}$, is given

$$
\left.f(x)=e^{\left\{-\frac{-(x-2) \underline{a}}{a}\right.}\right\}
$$

Normal probability density function is given by:

$$
f(x)=\frac{1}{\sigma \sqrt{2 \pi}} e^{\left\{-(x-\mu)^{2} /\left(2 \sigma^{5}\right)\right\}}
$$

in which,

$\boldsymbol{\mu}$ is the location parameter, and

$\sigma$ is the scale one.

Pearson III distribution with parameters $\boldsymbol{\mu}, \boldsymbol{\sigma}$ and $Y$, is given by:

$$
f(x)=\frac{|x-\xi|^{\alpha-1} e^{-|x-\xi| c \mid \beta}}{\beta^{\alpha} \Gamma(\alpha)}
$$

in which,

$$
\alpha=\frac{1}{\gamma^{2}} ; \beta=\frac{1}{2} \sigma|\gamma| \text { e } \xi=\frac{\mu-2 \sigma}{\gamma}
$$

Weibull distribution, with location parameter $\zeta$, scale $\beta$, and form $\delta$, has the following probability density function:

$$
f(x)=1-e^{\left[\{(x-\varphi) \beta]^{\S}\right]}
$$

Lognormal probability density function with parameters, ${ }^{\mu_{\ln (x)}}$ and ${ }^{\sigma_{\ln (x)}}$, is given by:

$$
f(x)=\frac{1}{x \sigma_{\ln (x)} \sqrt{2 \pi}} e^{\left\{-\left(\ln (x)-\mu_{\ln (x)}\right)^{2} /\left(2 \sigma_{\ln (x)}, 2\right)\right.}
$$
by:

Lognormal probability density function with three parameters $\left(a,{ }^{\mu} \ln (x)\right.$ and ${ }^{\left.\sigma_{\ln (x)}\right)}$ is given

$$
\left.f(x)=\frac{1}{(x-a) \sigma_{\ln (x)} \sqrt{2 \pi}} e^{\left\{-\left(\ln (x-a)-\mu_{\ln (x)}\right)^{2}\left(2 \sigma_{\ln (x)}\right)\right.}\right\}
$$


Lastly, beta probability density function with parameters $\boldsymbol{\alpha}$ and $\boldsymbol{\beta}$ is given by:

$$
f(x)=\frac{1}{B(\alpha, \beta)} x^{\alpha-1}(1-x)^{\beta-1}
$$

in which,

$$
B(\alpha, \beta)=\int_{0}^{1} t^{\alpha-1}(1-t)^{\beta-1} d t
$$

The parameters of the distributions were estimated by the L-moment method (HOSKING \& WALLIS, 1997). MARTINS et al. (2011) stated that this method has been proposed to estimate parameters of the main probability distributions for hydrological studies.

ALVES et al. (2013) ascertained that the L-moment method estimates parameters of similar quality resulting from the maximum likelihood method.

The Kolmogorov-Smirnov a test was used to check the fit of the probability distributions to the $\mathrm{ET}_{0}$ data series $\left(\mathrm{mm}\right.$ day $\left.^{-1}\right)$, at $20 \%$ significance level. This level was chosen to make this hypothesis test stricter as an increase in significance level reduces the critical value of the test statistics. The test was performed by following the procedures described by NAGHETTINI \& PINTO (2007).

Once the theoretical probability distribution with a good fit to the $\mathrm{ET}_{0}$ dataset was determined, a probable reference evapotranspiration was estimated as having probability inferior or equal to $75 \%$, i.e. every four years on average. Therefore, the probable $\mathrm{ET}_{0}$ was reached or exceeded, at least once.

\section{RESULTS AND DISCUSSION}

Table 2 show the results of the Kolmogorov-Smirnov good-fit test for the analyzed distributions, using "ns" for non-significant data at $20 \%$ probability $(\mathrm{p}>0.20)$ and "** for significant data at $20 \%(\mathrm{p}<0.20)$. Therefore, we noted that theoretical distributions with $\mathrm{p}$-value above 0.20 had a good fit to the reference evapotranspiration dataset $\left(\mathrm{ET}_{0}\right)$.

We might also see in Table 2 that GN distribution was the only that fitted to the $\mathrm{ET}_{0}$ dataset $\left(\mathrm{mm}\right.$ day $\left.^{-1}\right)$ for all studied months and locations. Furthermore, it is noteworthy that GEV, P3, GLO, and $\mathrm{W}$ distributions had also a good fit to $\mathrm{ET}_{0}$ dataset.

Conversely, gamma, normal, and Gumbel distributions showed a good fit for $\mathrm{ET}_{0}$ data series only in few months of the year, in the studied locations, whereas LN2 and LN3 probability distributions and beta presented no good fit to the dataset for any of the locations under study, as seen in Table 2.

In a study performed in Bahia state (Brazil), SILVA et al. (1998) observed that the best-fitted probability distributions to the $\mathrm{ET}_{0}$ data were normal, lognormal, and beta. Among the theoretical distributions analyzed by these authors, only the normal one fitted to $\mathrm{ET}_{0}$ data at certain times of the year, within the eight studied locations in the state of Espírito Santo (Table 2).

The GEV distribution fitted to the $\mathrm{ET}_{0}$ data series in virtually every month and sites, except for June and February in Presidente Kennedy and São Mateus, respectively. Likewise, GLO had a similar result to GEV (Table 2).

Considering that GN was the only one to fit the $\mathrm{ET}_{0}$ data $\left(\mathrm{mm} \mathrm{day}^{-1}\right)$ in all months and localities (Table 2), we may see in Table 3 the parameters, Kolmogorov-Smirnov test results (KS) and the estimated $\mathrm{ET}_{0}$ at $75 \%$ probability. 
TABLE 2. Results of the Kolmogorov-Smirnov fitting test, at $20 \%$ significance, for the assessed probabilistic distributions.

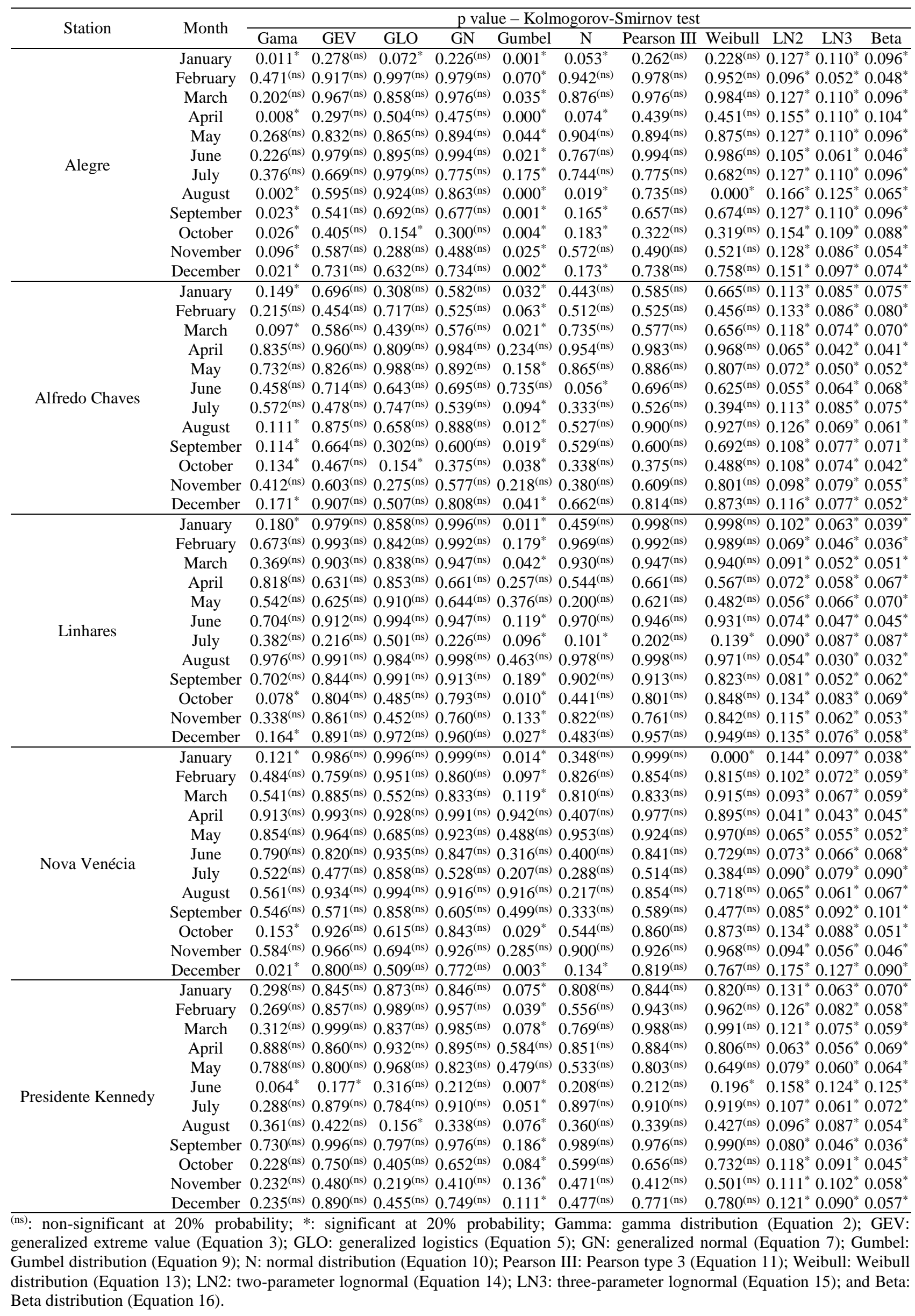


TABLE 2. Results of the Kolmogorov-Smirnov fitting test, at $20 \%$ significance, for the assessed probabilistic distributions.

(Continuation)

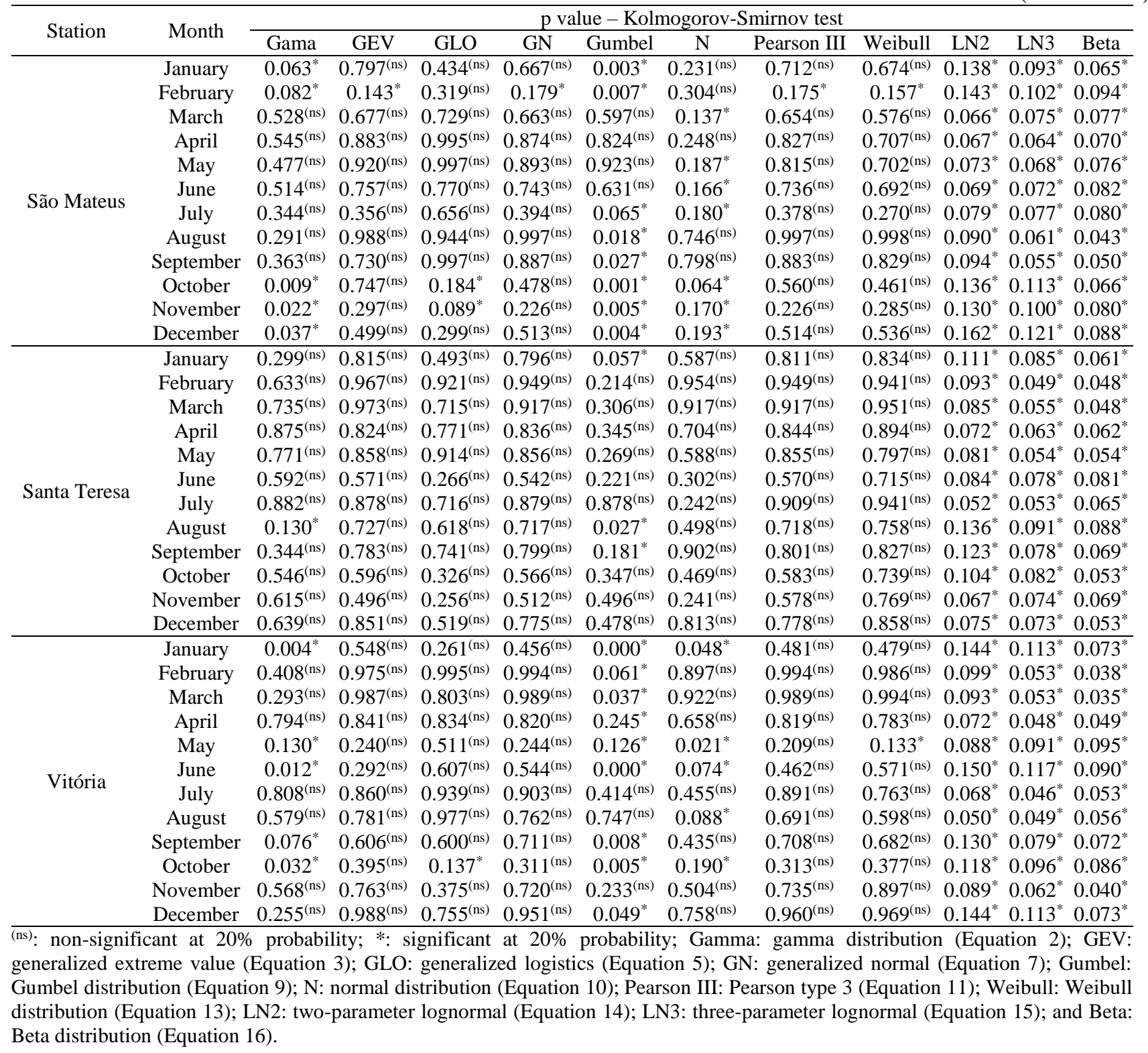


TABLE 3. Parameters of the generalized normal distribution (GN), KS test p-value and estimated $\mathrm{ET}_{0}$ at $75 \%$ probability for the studied stations.

\begin{tabular}{|c|c|c|c|c|c|c|}
\hline \multirow[b]{2}{*}{ Station } & \multirow{2}{*}{ Month } & \multicolumn{3}{|c|}{ Parameters } & \multirow{2}{*}{ p-value ${ }^{(4)}$} & \multirow{2}{*}{$\mathrm{ET}_{0}-75 \%\left(\mathrm{~mm}\right.$ day $\left.^{-1}\right)$} \\
\hline & & $\bar{\xi}(1)$ & a (2) & $\mathbf{K}_{(3)}$ & & \\
\hline \multirow{12}{*}{ Alegre } & January & 5.404 & 1.434 & 0.244 & $0.226^{\text {(ns) }}$ & 6.3 \\
\hline & February & 6.082 & 1.343 & 0.086 & $0.979^{\text {(ns) }}$ & 7.0 \\
\hline & March & 4.993 & 1.503 & 0.048 & $0.976^{(\mathrm{ns})}$ & 6.0 \\
\hline & April & 3.690 & 0.831 & 0.205 & $0.475^{\text {(ns) }}$ & 4.2 \\
\hline & May & 3.270 & 0.896 & -0.004 & $0.894^{(\mathrm{ns})}$ & 3.9 \\
\hline & June & 2.865 & 0.660 & 0.103 & $0.994^{(\mathrm{ns})}$ & 3.3 \\
\hline & July & 3.271 & 0.842 & 0.016 & $0.775^{\text {(ns) }}$ & 3.8 \\
\hline & August & 3.540 & 0.618 & 0.397 & $0.863^{\text {(ns) }}$ & 5.1 \\
\hline & September & 4.476 & 1.054 & 0.187 & $0.677^{(\mathrm{ns})}$ & 5.3 \\
\hline & October & 4.498 & 1.265 & 0.221 & $0.300^{\text {(ns) }}$ & 5.5 \\
\hline & November & 4.450 & 1.516 & 0.062 & $0.488^{\text {(ns) }}$ & 6.5 \\
\hline & December & 5.567 & 1.499 & 0.193 & $0.734^{\text {(ns) }}$ & 6.5 \\
\hline \multirow{12}{*}{ Alfredo Chaves } & January & 5.357 & 1.578 & 0.059 & $0.582^{\text {(ns) }}$ & 6.4 \\
\hline & February & 5.935 & 1.372 & 0.015 & $0.525^{(\mathrm{ns})}$ & 6.9 \\
\hline & March & 4.621 & 1.647 & -0.040 & $0.576^{(\mathrm{ns})}$ & 5.7 \\
\hline & April & 3.406 & 0.910 & -0.083 & $0.984^{\text {(ns) }}$ & 4.0 \\
\hline & May & 3.073 & 0.761 & -0.106 & $0.892^{\text {(ns) }}$ & 3.6 \\
\hline & June & 2.780 & 0.821 & -0.258 & $0.695^{\text {(ns) }}$ & 3.4 \\
\hline & July & 3.025 & 0.766 & -0.127 & $0.539^{\text {(ns) }}$ & 3.6 \\
\hline & August & 3.431 & 0.891 & 0.162 & $0.888^{(\mathrm{ns})}$ & 4.0 \\
\hline & September & 4.011 & 1.175 & 0.021 & $0.600^{\text {(ns) }}$ & 4.8 \\
\hline & October & 3.892 & 1.404 & -0.022 & $0.375^{(\mathrm{ns})}$ & 4.8 \\
\hline & November & 4.071 & 1.750 & -0.181 & $0.577^{(\mathrm{ns})}$ & 5.3 \\
\hline & December & 5.013 & 1.555 & 0.088 & $0.808^{(\mathrm{ns})}$ & 6.0 \\
\hline \multirow{12}{*}{ Linhares } & January & 5.469 & 1.036 & 0.228 & $0.996^{\text {(ns) }}$ & 6.1 \\
\hline & February & 5.467 & 1.154 & 0.035 & $0.992^{\text {(ns) }}$ & 6.2 \\
\hline & March & 5.092 & 1.169 & 0.008 & $0.947^{(\mathrm{ns})}$ & 5.9 \\
\hline & April & 4.057 & 0.854 & -0.032 & $0.661^{\text {(ns) }}$ & 4.6 \\
\hline & May & 3.496 & 0.779 & -0.177 & $0.644^{(\mathrm{ns})}$ & 4.1 \\
\hline & June & 3.114 & 0.657 & -0.065 & $0.947^{\text {(ns) }}$ & 3.6 \\
\hline & July & 2.928 & 0.661 & -0.234 & $0.226^{(\mathrm{ns})}$ & 3.4 \\
\hline & August & 3.246 & 0.649 & -0.039 & $0.998^{\text {(ns) }}$ & 3.7 \\
\hline & September & 4.218 & 0.950 & -0.020 & $0.913^{\text {(ns) }}$ & 4.9 \\
\hline & October & 4.211 & 1.160 & 0.109 & $0.793^{\text {(ns) }}$ & 5.0 \\
\hline & November & 4.502 & 1.561 & 0.037 & $0.760^{\text {(ns) }}$ & 5.5 \\
\hline & December & 5.671 & 1.228 & 0.201 & $0.960^{\text {(ns) }}$ & 6.4 \\
\hline \multirow{12}{*}{ Nova Venécia } & January & 5.953 & 1.128 & 0.351 & $0.999^{\text {(ns) }}$ & 6.6 \\
\hline & February & 5.523 & 1.013 & 0.107 & $0.860^{(\mathrm{ns})}$ & 6.2 \\
\hline & March & 4.465 & 0.917 & -0.019 & $0.833^{\text {(ns) }}$ & 5.1 \\
\hline & April & 4.074 & 1.059 & -0.285 & $0.991^{(\mathrm{ns})}$ & 4.9 \\
\hline & May & 3.281 & 0.718 & -0.051 & $0.923^{\text {(ns) }}$ & 3.8 \\
\hline & June & 2.737 & 0.558 & -0.161 & $0.847^{\text {(ns) }}$ & 3.1 \\
\hline & July & 3.024 & 0.584 & -0.133 & $0.528^{(\mathrm{ns})}$ & 3.4 \\
\hline & August & 3.546 & 0.875 & -0.323 & $0.916^{(\mathrm{ns})}$ & 4.2 \\
\hline & September & 4.198 & 0.801 & -0.155 & $0.605^{(\mathrm{ns})}$ & 4.8 \\
\hline & October & 4.362 & 1.131 & 0.189 & $0.843^{(\mathrm{ns})}$ & 5.1 \\
\hline & November & 4.284 & 1.508 & -0.021 & $0.926^{(\mathrm{ns})}$ & 5.3 \\
\hline & December & 5.383 & 1.418 & 0.285 & $0.772^{\text {(ns) }}$ & 6.3 \\
\hline \multirow{12}{*}{ Presidente Kennedy } & January & 6.662 & 1.849 & 0.126 & $0.846^{\text {(ns) }}$ & 7.9 \\
\hline & February & 6.789 & 1.179 & 0.243 & $0.957^{\text {(ns) }}$ & 7.5 \\
\hline & March & 4.523 & 1.210 & 0.162 & $0.985^{\text {(ns) }}$ & 5.3 \\
\hline & April & 3.901 & 1.054 & -0.161 & $0.895^{\text {(ns) }}$ & 4.7 \\
\hline & May & 3.220 & 0.880 & -0.169 & $0.823^{\text {(ns) }}$ & 3.8 \\
\hline & June & 2.601 & 0.539 & 0.003 & $0.212^{\text {(ns) }}$ & 3.0 \\
\hline & July & 3.131 & 0.856 & 0.006 & $0.910^{\text {(ns) }}$ & 3.7 \\
\hline & August & 3.743 & 0.962 & 0.024 & $0.338^{\text {(ns) }}$ & 4.4 \\
\hline & September & 4.327 & 1.077 & 0.037 & $0.976^{(\mathrm{ns})}$ & 5.0 \\
\hline & October & 3.949 & 1.315 & 0.072 & $0.652^{\text {(ns) }}$ & 4.8 \\
\hline & November & 4.643 & 1.743 & -0.049 & $0.410^{\text {(ns) }}$ & 5.8 \\
\hline & December & 5.709 & 1.755 & 0.171 & $0.750^{(\mathrm{ns})}$ & 6.8 \\
\hline
\end{tabular}


TABLE 3. Parameters of the generalized normal distribution (GN), KS test p-value and estimated $\mathrm{ET}_{0}$ at $75 \%$ probability for the studied stations.

(Continuation)

\begin{tabular}{|c|c|c|c|c|c|c|}
\hline \multirow{2}{*}{ Station } & \multirow{2}{*}{ Month } & \multicolumn{3}{|c|}{ Parameters } & \multirow{2}{*}{ p-value ${ }^{(4)}$} & \multirow{2}{*}{$\mathrm{ET}_{0}-75 \%\left(\mathrm{~mm} \mathrm{day}^{-1}\right)$} \\
\hline & & $\xi(1)$ & $\mathbf{\alpha}(2)$ & $\mathbf{K}$ & & \\
\hline \multirow{12}{*}{ São Mateus } & January & 5.601 & 1.007 & 0.284 & $0.667^{\text {(ns) }}$ & 6.2 \\
\hline & February & 5.559 & 1.175 & 0.129 & $0.201^{(\mathrm{ns})}$ & 6.3 \\
\hline & March & 4.959 & 1.194 & -0.197 & $0.663^{\text {(ns) }}$ & 5.8 \\
\hline & April & 3.517 & 0.628 & -0.288 & $0.874^{(\mathrm{ns})}$ & 4.0 \\
\hline & May & 3.080 & 0.690 & -0.366 & $0.893^{(\mathrm{ns})}$ & 3.6 \\
\hline & June & 2.720 & 0.645 & -0.232 & $0.743^{(\mathrm{ns})}$ & 3.2 \\
\hline & July & 2.719 & 0.524 & -0.151 & $0.394^{(\mathrm{ns})}$ & 3.1 \\
\hline & August & 3.091 & 0.570 & 0.112 & $0.997^{\text {(ns) }}$ & 3.5 \\
\hline & September & 4.049 & 0.706 & 0.081 & $0.887^{\text {(ns) }}$ & 4.5 \\
\hline & October & 4.102 & 1.037 & 0.290 & $0.478^{\text {(ns) }}$ & 4.7 \\
\hline & November & 4.385 & 1.555 & 0.041 & $0.226^{(\mathrm{ns})}$ & 5.4 \\
\hline & December & 5.465 & 1.397 & 0.138 & $0.513^{\text {(ns) }}$ & 6.4 \\
\hline \multirow{12}{*}{ Santa Teresa } & January & 4.281 & 1.136 & 0.149 & $0.796^{\text {(ns) }}$ & 5.0 \\
\hline & February & 4.525 & 1.018 & 0.072 & $0.940^{\text {(ns) }}$ & 5.2 \\
\hline & March & 3.597 & 1.181 & -0.001 & $0.917^{(\mathrm{ns})}$ & 4.4 \\
\hline & April & 2.893 & 0.844 & -0.206 & $0.836^{(\mathrm{ns})}$ & 3.5 \\
\hline & May & 2.324 & 0.625 & -0.078 & $0.856^{\text {(ns) }}$ & 2.8 \\
\hline & June & 1.859 & 0.534 & -0.180 & $0.542^{\text {(ns) }}$ & 2.2 \\
\hline & July & 2.242 & 0.871 & -0.326 & $0.879^{\text {(ns) }}$ & 2.9 \\
\hline & August & 2.603 & 0.729 & 0.072 & $0.717^{(\mathrm{ns})}$ & 3.1 \\
\hline & September & 3.124 & 1.248 & -0.110 & $0.799^{\text {(ns) }}$ & 4.0 \\
\hline & October & 2.789 & 1.196 & -0.149 & $0.566^{\text {(ns) }}$ & 3.6 \\
\hline & November & 2.844 & 1.296 & -0.272 & $0.512^{\text {(ns) }}$ & 3.8 \\
\hline & December & 3.821 & 1.421 & -0.058 & $0.775^{\text {(ns) }}$ & 4.8 \\
\hline \multirow{12}{*}{ Vitória } & January & 5.779 & 1.492 & 0.229 & $0.456^{\text {(ns) }}$ & 6.7 \\
\hline & February & 5.691 & 1.224 & 0.080 & $0.994^{\text {(ns) }}$ & 6.5 \\
\hline & March & 4.921 & 1.277 & 0.044 & $0.989^{\text {(ns) }}$ & 5.8 \\
\hline & April & 4.246 & 1.073 & -0.041 & $0.820^{\text {(ns) }}$ & 5.0 \\
\hline & May & 3.082 & 0.768 & -0.268 & $0.244^{(\mathrm{ns})}$ & 3.7 \\
\hline & June & 2.564 & 0.468 & 0.290 & $0.544^{(\mathrm{ns})}$ & 2.9 \\
\hline & July & 2.967 & 0.778 & -0.142 & $0.903^{\text {(ns) }}$ & 3.5 \\
\hline & August & 3.464 & 1.045 & -0.339 & $0.762^{(\mathrm{ns})}$ & 4.3 \\
\hline & September & 4.196 & 1.082 & 0.077 & $0.711^{\text {(ns) }}$ & 4.9 \\
\hline & October & 4.171 & 1.258 & 0.065 & $0.311^{\text {(ns) }}$ & 5.0 \\
\hline & November & 4.624 & 1.710 & -0.124 & $0.720^{\text {(ns) }}$ & 5.8 \\
\hline & December & 5.676 & 1.543 & 0.179 & $0.951^{\text {(ns) }}$ & 6.7 \\
\hline
\end{tabular}

(ns): non-significant at 20\% probability by the Kolmogorov-Smirnov test; (1) Location parameter; (2) Scale parameter; and (3) Form parameter.

Figure 2 shows the $\mathrm{ET}_{0}$ variation estimated at $75 \%$ probability throughout the year. An analysis of the graph in Figure 2 showed that the higher ET $_{0}$ rates occur from December to February (from 4.8 to $7.9 \mathrm{~mm} \mathrm{day}^{-1}$ ), while the lowest ones are between May and July (from 2.2 to $4.1 \mathrm{~mm}$ $\mathrm{dia}^{-1}$ ) (Table 3). It is noteworthy that the highest $\mathrm{ET}_{0}$ values match the period of high rainfalls, and the lowest ones with less rainfall when taking into account the results obtained by ULIANA et al. 2013). 


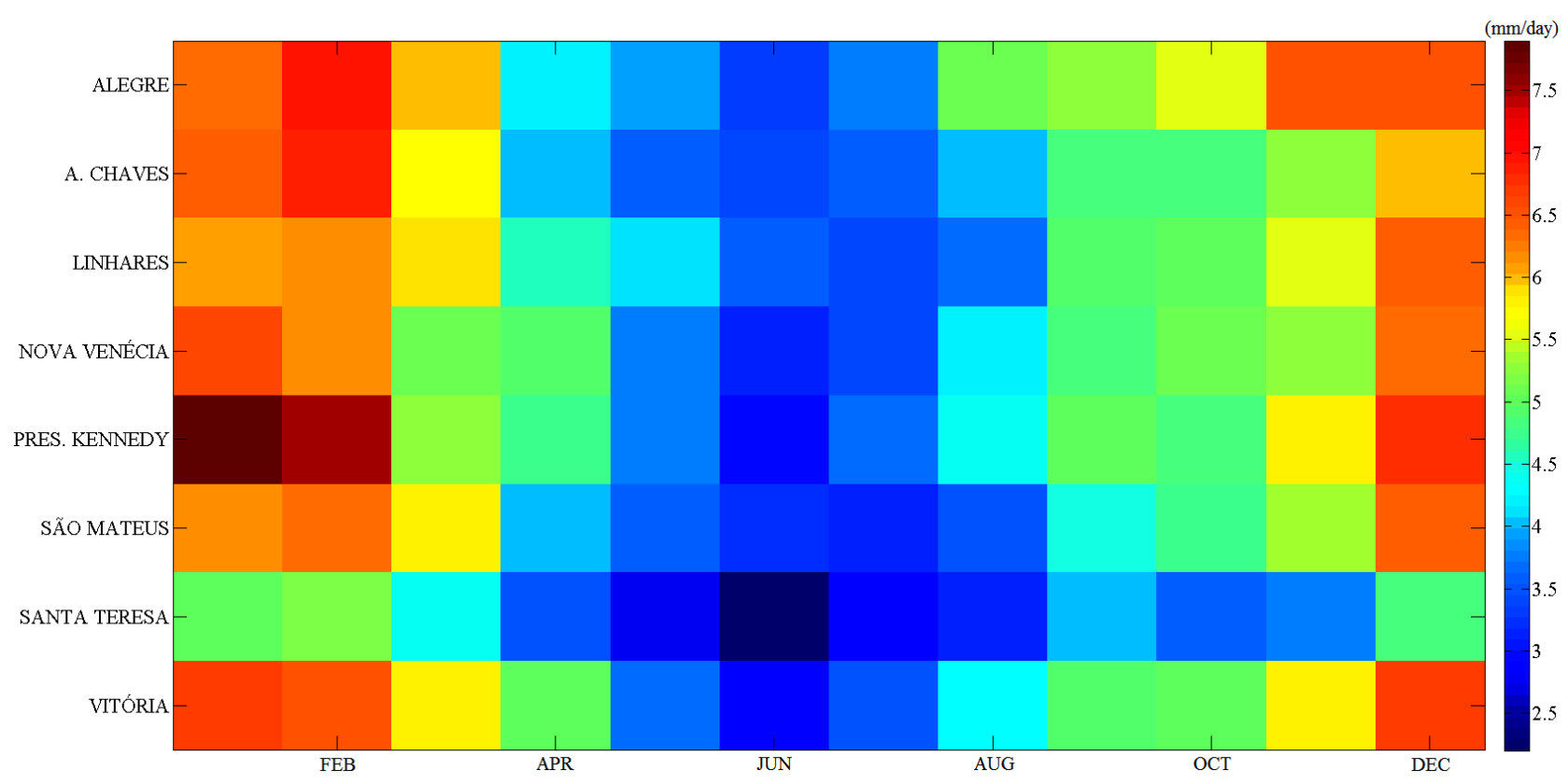

FIGURE 2. Variation in the reference evapotranspiration estimated on generalized normal distribution (GN) at $75 \%$ probability during the year

In the months of March, April, August, September, and October, ET $_{0}$ estimated at $75 \%$ probability ranged from 3.1 to $6.0 \mathrm{~mm}^{-1}$ day $^{-1}$ (Table 3 ).

The highest value of $\mathrm{ET}_{0}$ was recorded in January, in Presidente Kennedy (7.9 mm day-1). This outcome was already expected since this area has high wind speeds and temperatures. On the other side, the lowest values were registered in the city of Santa Teresa, located in the highlands of the state.

In light of the role played by the management of water resources in irrigated farming, all the information shown in Table 3, as well as $\mathrm{ET}_{0}$ behavior throughout the year, are fundamental for estimation of effective irrigation intervals and applied water depth, avoiding irrigation water waste (MANTOVANI et al., 2009).

In this study, we have solely estimated $\mathrm{ET}_{0}$ rates at $75 \%$ probability; however, making use of the parameters of a generalized normal distribution, shown in Table 3, we can estimate it at other probability levels, enabling the draughtsman to choose a proper degree of risk.

\section{CONCLUSIONS}

The Generalized Normal, Generalized Extreme Values, Pearson III, Generalized Logistics, and Weibull distributions showed a good fit to the $\mathrm{ET}_{0}$ data, with Generalized Normal being the one that properly described the data (in $\mathrm{mm} \mathrm{day}^{-1}$ ) for all the months and locations under study in the state of Espírito Santo (Brazil).

Continuous probability models can be used to estimate daily reference evapotranspiration associated with a certain level of risk, allowing the acquisition of probable $\mathrm{ET}_{0}$ data for irrigation system sizing purposes.

\section{ACKNOWLEDGEMENTS}

The authors thank the Foundation for Research Support of the State of Minas Gerais (FAPEMIG) for granting a Ph.D. scholarship and to the Brazilian Institute of Meteorology (INMET) for making meteorological data available. 


\section{REFERENCES}

ALLEN, R.G.; PEREIRA, L.S.; RAES, D.; SMITH, M. Crop evapotranspiration: guidelines for computing crop water requirements. Rome: FAO, 1998. 300p. (Irrigation and Drainage Paper, 56).

ALVES, A.V.P.; SANTOS, G.B.S.; MENEZES FILHO, F.C.M.; SANCHES, L. Análise dos Métodos de Estimativa para os Parâmetros das Distribuições de Gumbel e GEV em Eventos de Precipitações Máximas na Cidade de Cuiabá - MT. Revista Eletrônica de Engenharia Civil, Goiânia, v. 6, n. 1, p.32-43, 2013.

ASSIS, J. P.; SOUSA, R. P.; BEZERRA NETO, F.; LINHARES, P. C. F. Tables of probabilities of reference evapotranspiration for the region of Mossoró, RN, Brazil. Revista Verde de Agroecologia e Desenvolvimento Sustentável, Pombal, v. 9, n. 3, p.58-67, 2014.

BARROS, V.R.; SOUZA, A.P.; FONSECA, D.C.; SILVA, L.B.D. Avaliação da evapotranspiração de referência na Região de Seropédica, Rio de Janeiro, utilizando lisímetro de pesagem e modelos matemáticos. Revista Brasileira de Ciências Agrárias, Recife, v. 4, n. 2, p.198-203, 2009.

BERNARDO, S; SOARES, A. A.; MANTOVANI, E. C. Manual de Irrigação. Viçosa: UFV, 2006. 625 p.

CAVALCANTE JUNIOR, E.G.; OLIVEIRA, A.D.; ALMEIDA, B.M.; SOBRINHO, J. E. Métodos de estimativa da evapotranspiração de referência para as condições do semiárido

Nordestino. Semina: Ciências Agrárias, Londrina, v. 32, n. 1, p.1699-1708, 2011.

HOSKING, J.R.M. Package 'Imom'. Disponível em: <http://cran.r-project.org/web/packages/ lmom/lmom.pdf>. Acesso em: 02 jul 2013.

HOSKING, J. R. M.; WALLIS, J. R. Regional frequency analysis: an approach based on Lmoments. Cambridge: Cambridge University Press, 1997. 224 p.

MANTOVANI, E.C.; BERNARDO, S.; PALARETTI, L.F. Irrigação: princípios e métodos. 3. ed. Viçosa: UFV, 2009. 355 p.

MARTINS, C.A.S.; ULIANA, E.M.; REIS, E.F. Estimativa da Vazão e da Precipitação Máxima utilizando Modelos Probabilísticos na Bacia Hidrográfica do Rio Benevente. Enciclopédia Biosfera, Goiânia, v. 7, n. 13, p.1130-1142, 2011.

NAGUETTINI, M.; PINTO, E. J. A. Hidrologia estatística. Belo Horizonte: CPRM, 2007. 552 p.

OLIVEIRA, L.M.M.; MONTENEGRO, S.M.G.L.; AZEVEDO, J.R.G.; SANTOS, F.X.

Evapotranspiração de referência na bacia experimental do riacho Gameleira, PE, utilizando-se lisímetro e métodos indiretos. Revista Brasileira de Ciências Agrárias, Recife, v. 3, n. 1, p.58-67, 2008.

SAAD, J.C.C.; BISCARO, G.A.; DELMANTO JUNIOR, O.; FRIZZONE, J.A. Estudo da Distribuição da Evapotranspiração de Referência Visando o Dimensionamento de Sistemas de Irrigação. Irriga, Botucatu, v. 1, n. 7, p.10-17, 2002.

SILVA, F.C.; FIETZ, C.R.; FOLEGATTI, M.V.; PEREIRA, F.A.C. Distribuição e Frequência da Evapotranspiração de Referência de Cruz das Almas, BA. Revista Brasileira de Engenharia Agrícola e Ambiental, Campina Grande, v. 2, n. 3, p.284-286, 1998.

ULIANA, E.M.; REIS, E.F.; SILVA, J.G.F.; XAVIER, A.C. Precipitação Mensal e Anual Provável para o Estado do Espírito Santo. Irriga, Botucatu, v. 18, n. 1, p.139-147, 2013. 